\title{
燃料電池の開発状況
}

\author{
株式会社東芝 電力システム社燃料電池事業推進部 白 岩 義 三
}

\section{Development of Fuel Cell Power Plant}

\section{Yoshimi Shiraiwa}

System Engineering Group. Fuel Cell Systems Division,

Power Systems \& Services Company. Toshiba Corporation

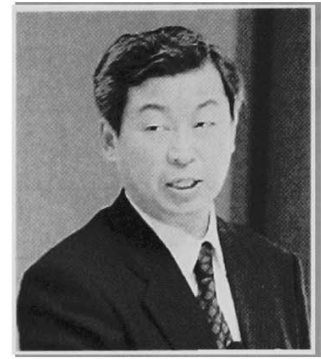

Since the control of greenhouse gas emissions is now an international issue of growing importance. the Fuel Cell Power Plant (FCPP) is increasingly expected as one of the most promising new technologies.

Phosphoric acid fuel cell power plants have been introduced at various commercial applications aimed at increasing overall energy efficiency while minimizing impact on the environment. ADG (Anaerobic Digester Gas) fueled FCPP and biogas fueled FCPP have been developed. Both ADG and biogas are produced from the methane fermentation process at water treatment facilities. In addition, a new application has been developed with waste-methanol, which is discharged from the product cleaning process in semiconductor industry.

And the new application for FCPP has been developed as a premium power supply for important load, providing constant voltage and constant frequency.

Polymer electrolyte fuel cells are applicable to various fields such as residences, and automobiles. and are developing with quick steps.

分類： $\mathrm{U}_{7}$ 電気, $\mathrm{Y}_{6}$ 物理化学, $\mathrm{X}_{3}$ 大気

\section{1.はじめに}

燃料電池は小型で高い発電効率を有し，環境特性に 優れた新しい発電装置として，罢境問題の重要さが增 している現在, 分散電源やコージェネレーションシス テム,さらには電気自動車の電源などへの適用に期待 が高まっている。中でも，りん酸形燃料電池 (PAFC) はその開発が完了し，本格的普及を推進すべき段階に 到達している。また，固体高分子形燃料電池 (PEFC) は定置用から自動車用まで幅広い用途に適用が可能で あり，現在実用化のための開発が進められている。

\section{2. 燃料電池の種類と特徴}

然料電池は，水素と酸素を電気化学的に反応させ， 燃料から直接的に電気エネルギーと熱エネルギーを同 時に取出すことのできるエネルギー変換装置である。 燃料電池の酸素/水素の王電極の間には電解質と呼ば れるイオン透過層があるが,この電解質の種類によっ て，表 1 に示す 5 種類に代表される。ここではりん酸

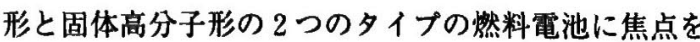
当て, その特徵や構成, 適用例, 開発動向等を紹介す る。 
表 1 燃料電池の種類と特徵

\begin{tabular}{|c|c|c|c|c|c|}
\hline & $\begin{array}{l}\text { りん酸形 } \\
\text { (PAFC) }\end{array}$ & $\begin{array}{c}\text { 固体高分子形 } \\
\text { (PEFC) }\end{array}$ & $\begin{array}{c}\text { 溶融炭酸塩形 } \\
(\mathrm{MCFC})\end{array}$ & $\begin{array}{c}\text { 固体電解質形 } \\
\text { (SOFC) }\end{array}$ & $\begin{array}{c}\text { アルカリ形 } \\
(\mathrm{AFC})\end{array}$ \\
\hline 電解質 & りん酸水溶液 & $\begin{array}{l}\text { スルフォン酸基 } \\
\text { 高分子膜 }\end{array}$ & $\begin{array}{l}\mathrm{Li}-\mathrm{Na} / \mathrm{Li}-\mathrm{K} \text { 系 } \\
\text { 炭酸塩 }\end{array}$ & $\begin{array}{l}\text { ジルコニア系セラ } \\
\text { ミックス }\end{array}$ & $\begin{array}{l}\text { 水酸化カリウム } \\
\text { 水溶液 }\end{array}$ \\
\hline $\begin{array}{l}\text { 動作 } \\
\text { 温度 } \\
\end{array}$ & $200^{\circ} \mathrm{C}$ & $70 \sim 90^{\circ} \mathrm{C}$ & $650 \sim 700^{\circ} \mathrm{C}$ & $900 \sim 1,000^{\circ} \mathrm{C}$ & $60 \sim 90^{\circ}$ \\
\hline 燃料 & $\begin{array}{l}\text { 天然ガスや LPG } \\
\text { などを改質した水 } \\
\text { 素リッチガス }\end{array}$ & $\begin{array}{l}\text { 天然ガスや LPG } \\
\text { などを改質した水 } \\
\text { 素リッチガス }\end{array}$ & $\begin{array}{l}\text { 天然ガスや石炭ガ } \\
\text { スを改質した水素 } \\
\text { リッチガス }\end{array}$ & $\begin{array}{l}\text { 天然ガスや石炭ガ } \\
\text { スを改質した水素 } \\
\text { リッチガス }\end{array}$ & 純水素 \\
\hline $\begin{array}{l}\text { 発電 } \\
\text { 効率 }\end{array}$ & $35 \sim 42 \%$ (LHV) & $30 \sim 40 \%$ (LHV) & $45 \sim 60 \%$ (LHV) & $45 \sim 60 \%$ (LHV) & $\begin{array}{l}\text { ６0\% (LHV) } \\
\text { (純水素·純酸素) }\end{array}$ \\
\hline 用途 & $\begin{array}{l}\text { 中小規模分散 } \\
\text { 電源/コージェネ }\end{array}$ & $\begin{array}{l}\text { 自動車用や小規模 } \\
\text { 分散電源 }\end{array}$ & $\begin{array}{l}\text { 中大規模分散電源 } \\
\text { やコンバインドサ } \\
\text { イクル }\end{array}$ & $\begin{array}{l}\text { 中大規模分散電源 } \\
\text { やコンバインドサ } \\
\text { イクル }\end{array}$ & $\begin{array}{l}\text { 宇宙/軍事など特 } \\
\text { 殊用途 }\end{array}$ \\
\hline
\end{tabular}

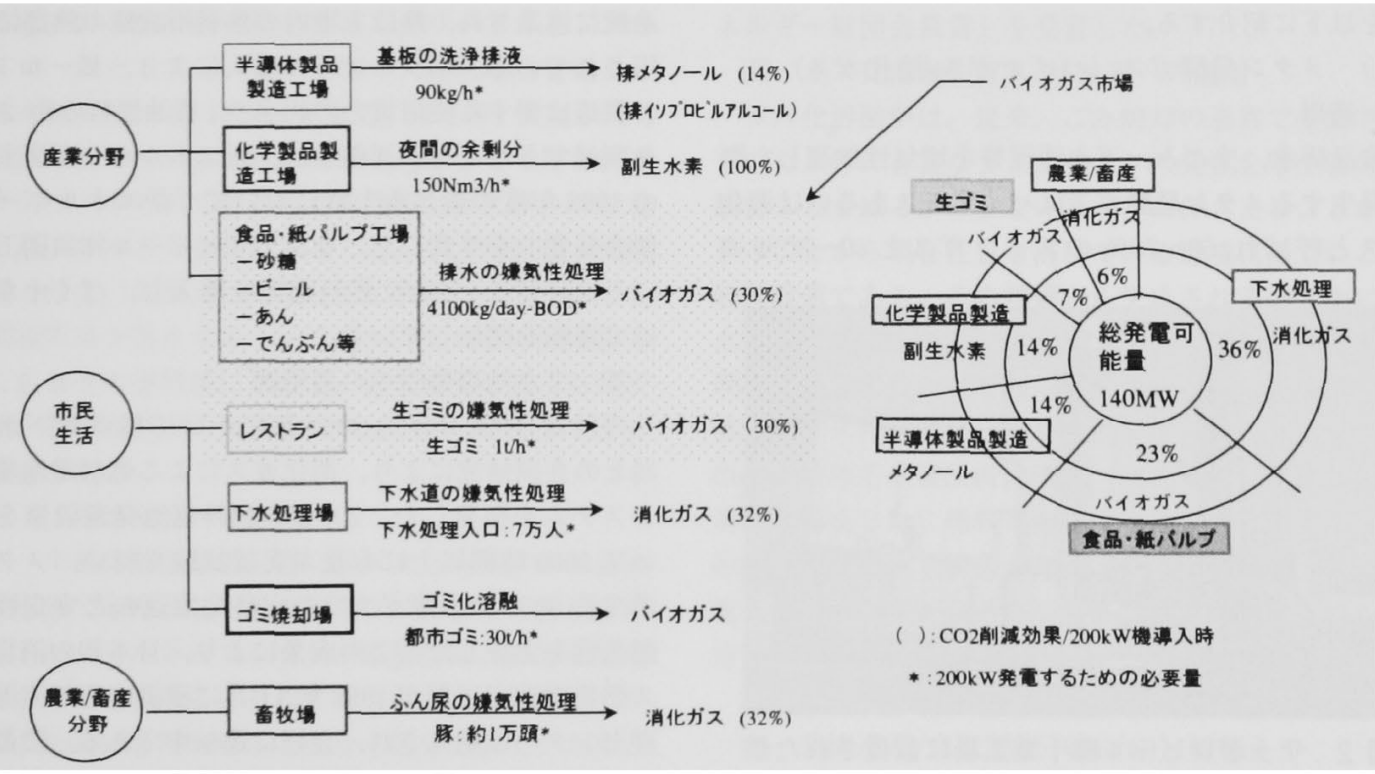

図 1 未利用エネルギーの種類とそれを利用することによる $200 \mathrm{~kW}$ 燃料電池にて発電可能量

\section{3. りん酸形燃料電池の現状}

\section{1 り酸形燃料電池の実用化}

りん酸形燃料電池の開発は, 日本においては 1980 年代より本格化し，その後 20 年間にわたり，国の支 援による開発プロジェクト，フィールドテスト等の助 成制度，及び民間の努力により進められてきた。その 結果として,りん酸形燃料電池は効率, 環境特性等の 性能面のみならず，酎久性，信頼性を格段に向上でき
た。日本では，これまで民生用（業務用）や産業用と して $50 \mathrm{~kW} \sim 200 \mathrm{~kW}$ 容量のプラントを中心に 100 台 以上が稼動してきたが，そのうち 13 台が商用化を前 提とした耐久性の目標である累皘運転 4 万時間を越え ている。りん酸形燃料電池は, 今まさに商用化段階に ある。燃料電池発電設備の製造コストも開発段階に比 へ，飛躍的な低減を達成しているが, 今後の本格的普 及のためには量産化によるさらなるコストダウンの推 進が必要であるとともに，燃料電池の特街を活かした 
新しい付加価値の創造とこれを用いた新用途の開拓及 び市場導入の推進が重要である。

\section{2 新用途への適用技術開発と市場導入事例}

\subsection{1 未利用エネルギーの燃料電池への適用}

燃料電池は, 水素を燃料として用いる発電装置であ ク，一般に都市ガスや LPG などの炭化水素類から水 素を作り発電に使用している。これらの燃料の代りに 今まで利用されずに捨てられていた食品工場等の排水 や下水污泥の嫌気性処理の際に発生するメタンリッチ ガスや工業廃棄物等をエネルギー源として活用できれ ば㻴境改善, 省資源, 経済性等多くの点で有効なシス テムの構築が可能となる。

燃料電池の燃料として, 利用可能な廃棄物及びその量 を, 産業, 市民生活, 農業/畜産の分野毎に当社にて 調查した一例を図 1 に示す。 $200 \mathrm{~kW}$ の容量の燃料電 池で, 定格発電するために必要なガスを発生する設備 を集計すると，総発電可能量は $140 \mathrm{MW}$ に相当する。 これら未利用エネルギーを燃料とした燃料電池の具体 例を以下に紹介する。

1）メタン発畩ガス（バイオガス/消化ガス）の 適用

食品排水，生ごみ，下水污泥等を嫌気性処理した際 に発生するメタン発醅ガスはバイオガスあるいは消化 ガスと呼ばれ, 60〜70\%のメタンガスと 40〜30\%の

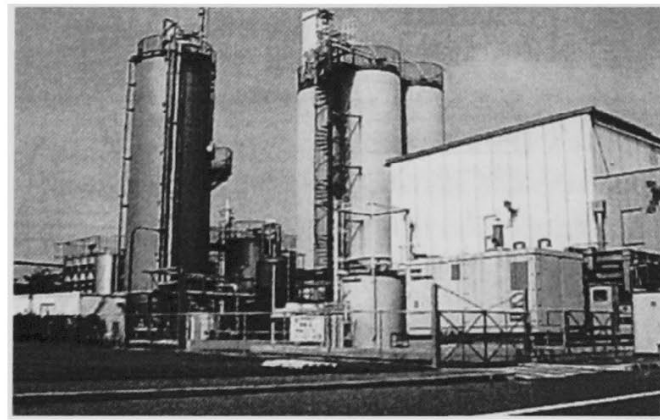

図 2 サッポロビール侏千葉工場に設置された燃 料電池
二酸化炭素で構成されるため低位発熱量が 22〜25 MJ $/ \mathrm{Nm}^{3}$ の低カロリーガスである。これらのバイオガス /消化ガスは燃焼の安定性や排ガスの性状等の点から 従来ボイラーや熱機関での利用に技術的配虑が必要で あったが, 電気化学的反応で発電する燃料電池の場合, その適用が比較的容易である。

（1）食品工場への適用例

バイオガスへの適用例として，サッポロビール(株) 千葉工場への導入事例を紹介する。本設備は「新エネ ルギー利用等の促進に関する特別措置法(新エネ法)」 による導入助成事業の適用対象となっている。

図 2 に設置状況を，図3にシステムを示す。ビール 工場の有機性廃水をメタン発醭槽にて浄化する際に発 生したバイオガスは，その中に含まれる不純物（硫化 水素, 塩類, アンモニア等) を除去する前処理装置を 経由して燃料電池発電設備に供給される。燃料電池発 電設備では，約 $80 \mathrm{Nm}^{3} / \mathrm{h}$ のバイオガスから $200 \mathrm{~kW}$ の電力と $740 \mathrm{MJ} / \mathrm{h}$ の熱を生成する。電力は工場内の 系統に連系され，熱は工場内の熱利用設備の熱源に利 用されている。本システムの導入により，ビール $1 \mathrm{k} l$ の製造に要する使用電力の約 $6 \%$,石油燃料の約 $2 \%$ を削减できたことが評価され，新エネルギー財団主催 の 1998 年度の新エネ大賞において「新エネルギー財 団会長賞」を受賞した。なおアサヒビール(侏四国工場 にも同時期に $200 \mathrm{~kW}$ 燃料電池を導入し，バイオガス にて運転を開始している。

（2）下水処理場等への適用例

当社は, 1994 年から 1998 年にかけて横浜市下水道 局との共同研究により，消化ガスによる燃料電池発電 システムを開発した。 $200 \mathrm{~kW}$ 燃料電池発電設備を用 いて 5000 時間以上にも及ぶ実証試験を行い，メタン 濃度約 $60 \%$ の希薄ガスでの定格発電運転と安定性, 耐久性を実証した。この成果により，日本初の消化ガ 又燃料電池実用機が 1999 年 11 月に横浜市北部污泥処 理センターに納入され，良好に運転中である。設置状 況を図 4 に示す。この燃料電池システムは，財環境調

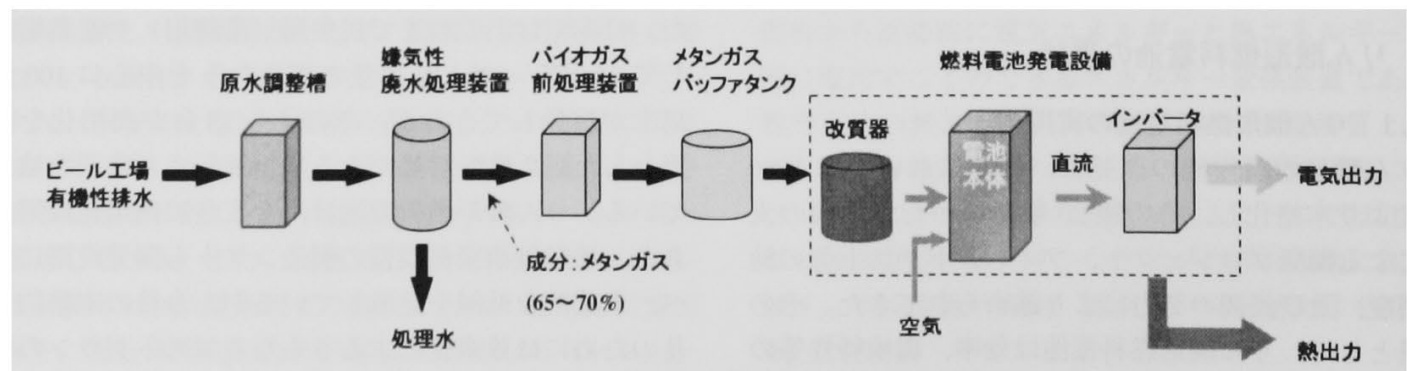

図 3 サッポロビール(株千葉工場燃料電池設備のシステム構成 

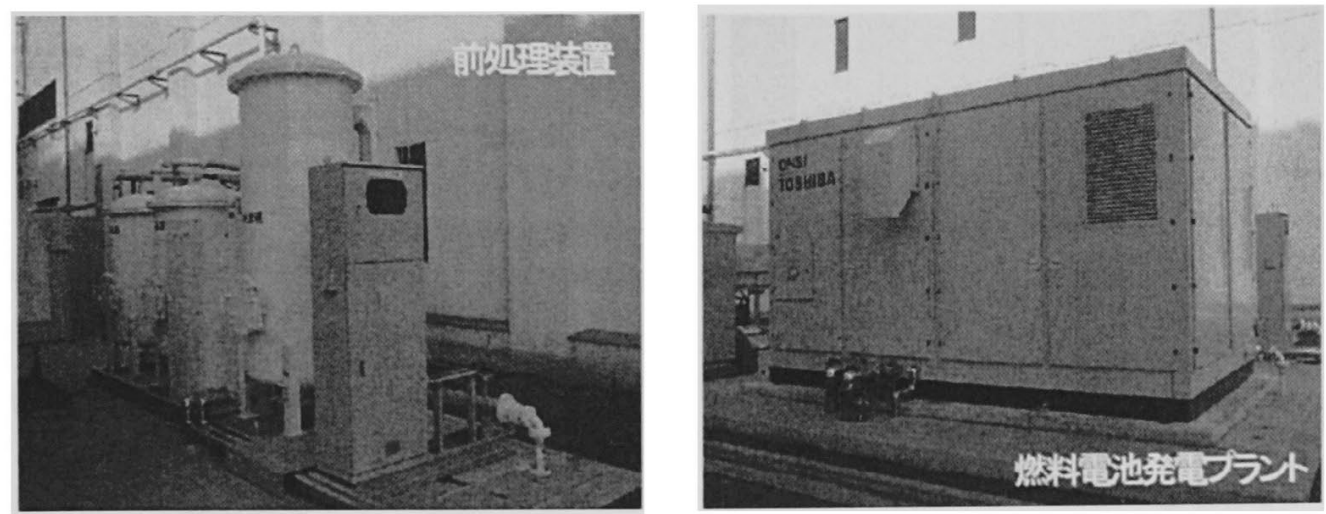

図 4 横浜市北部污泥処理センターに設置された燃料電池

査センターが主催する第 27 回環境賞（2000 年度）に おいて「優良賞」を受賞した。

また，家畜 (牛, 豚、鴿等) の排泄物も，メタン発 酵により浄化できるとともに，貴重な未利用エネルギ 一源となる。NEDO（新エネルギー・産業技術総合開 発機桠) は, 国祭研究協力事業（グリーンエイドプラ ン）の一環として「メタン発醭ガス燃料電池発電シス テムの実用化に関する研究協力」を 1999 年度から 4 年計画で進めている。豚の䔬尿を発醭させて得られる メタンリッチガスで燃料電池を運転し，クリーンな電 カと熱エネルギーを供給するとともに, 廃液は水処理 設備で浄化, 固形分は堆肥化して農業に活用すること で環境污染を防止するトータルシステムを中国と協力 して広東省の養豚場に建設し, 運転研究を行う計画で ある。豚約 1 万頭の排泄物で $200 \mathrm{~kW}$ の発電ができる 見通しである。

2）工業廃棄物への適用

（1）半導体製品製造工場（排メタノール）への適用 半導体工場や液晶工場の製造プロセスから排出され る排メタノール等のアルコール系物質は, 従来産業廃 菓物として処理業者に有償で引き渡され，焼却等の手 段で，有効に活用されることなく処分されていたが， これを積極的に燃料電池で利用することにより資源の 有効利用を図ることが可能となる。排メタノール中の 不純物を除去した後，メタノールを気化させることに より，通常のガス燃料と同じように燃料電池発電設備 の燃料として利用できる。セイコーエプソン(株豊科事 業所には，排メタノールを燃料とした $200 \mathrm{~kW}$ 燃料電 池発電設備 2 台 (図 5 参照) が設置され, 得られた電 力は工場の系統に連系され, 工場内で消費される。シ ステムを図 6 に示す。また，同時に発生する熟は蒸気 と温水の形で, 圶調や工場の製造ブロセスで使用する 純水の加温に利用されている。200 kW ×2台の然料
電池の導入により, 工場から発生する二酸化炭素を $14.5 \%$ 削減でき, 年間重油換算で $337 \mathrm{k} l$ のエネルギ 一を削減することができた。なお，この設備は工業廃 棄物を燃料電池の燃料として使用したリサイクル性と 先進性が評価され, 1999 年度の新エネ大賞にて「新工 ネルギー財団会長賞」を受賞した。

（2）ガス化溶融炬ガス/排水素への適用

ガス化溶融炉は, 従来, ごみ焼却の過程で生成され ていた人体に有害なダイオキシンの発生を厚生省の規 制値よりもはるかに少ないレベルに押さえることがで きることから現在注目を浴びている環境に優しいごみ 処理設備である。この設備から生成されるガス中には, 水素, 二酸化炭素, 一酸化炭素を含んでいることから 燃料電池の燃料として利用可能である。この環境性に 優れたガス化溶融炉と燃料電池を組合せたシステムが 川崎製鉄侏千葉製鉄所に導入（図 7 参照）され，発電 運転を開始した。燃料電池の水素供給源として, 上記 のほかに半導体工場のシリコンウェハー製造プロセス, 電気分解やソーダ製造プロセス等からの副生水素も利 用可能である。

\section{2 .2 高品質・高信頼性電力供給システム}

1) 系統連系/自立運転 (GC/GI) 切替え

然料電池は通常コージェネレーションシステムとし て系統連系運転を行っているが, 系統に停電が発生し た時に自動的に自立運転に切替え，一種の非常電源と して運用することが可能である。標準的には変換装置 に内蔵のブレーカは機械式であるため, 切替えには停 電検出時間も含めて 1 2 秒程度時間がかかるが, サ イリスタスイッチを組合せれば $1 / 2$ サイクル程度の瞬 断で切替えが可能となる。これは，コージェネレーシ ヨンを基本機能とする燃料電池にSPS（常時系統給 電型 UPS (無停電電源装置)) と同等な機能を付加す るものである。図 8 にこの無瞬断切替えシステムの構 


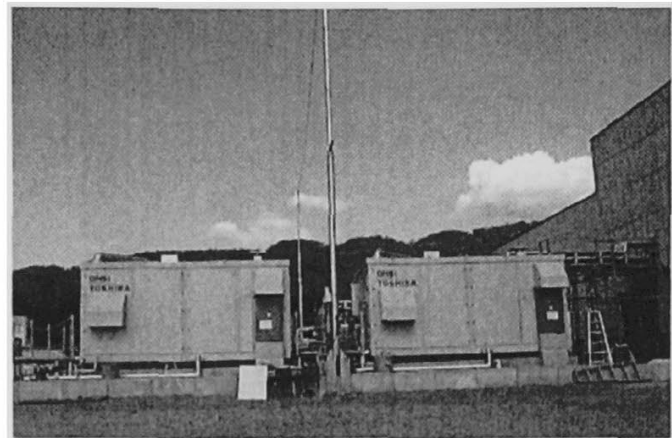

図 5 セイコーエブソン侏豊科事業所に設置され た燃料電池

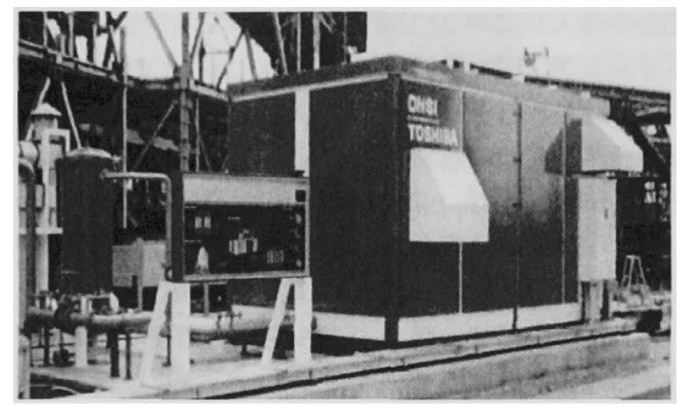

図 7 川崎製鉄侏千葉製鉄所に導入された燃料電 池

造図を示す。

2) UPS 融合システム

従来, 重要負荷への安定電源確保のためには, UPS と長時間の電力供給用の非常用発電機を組合せた電源 供給システムが用いられてきた。これと同等に機能し， かつランニンクコストが従来の UPSに比べ有利な電 源供給システムとして高品質・高信頼性電力供給シス テムを開発した。そのシステム構成を図 9 に示す。こ のシステムは, 当社の $200 \mathrm{~kW} り ん$ 酸形燃料電池 PC $25^{\mathrm{TM}} \mathrm{C}$ に梆準搭載されているインパータの代りに, DC /DC コンバータを組込み，燃料電池を直流出力型に 改造し, その直流出力を $200 \mathrm{kVA}$ の汎用 UPS の直流 部分に接続したものである。

このような構成とすることにより, UPS内のイン パータにより直流出力を交流電力に変換し独立(重要) 負荷へ供給すると同時に，交流/直流変換装置（整流 器）を逆動作（双方向インバー夕）させることにより， 余㮃直流電力を交流電力に変換し系統へ連系連転させ ている。さらにインバータ故障時のバックアップとし て高速スイッチ（サイリスタ）による電力系統の直接 受電機能や, 都市ガス等の主然料が絗たれた場合の尒

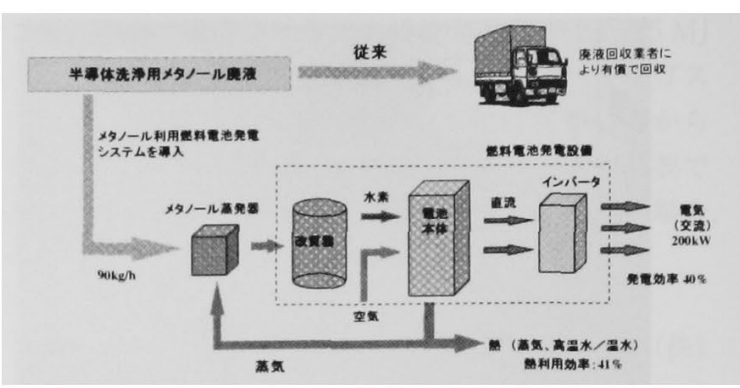

図 6 セイコーエプソン(㧣豊科事業所の燃料電池の システム構成

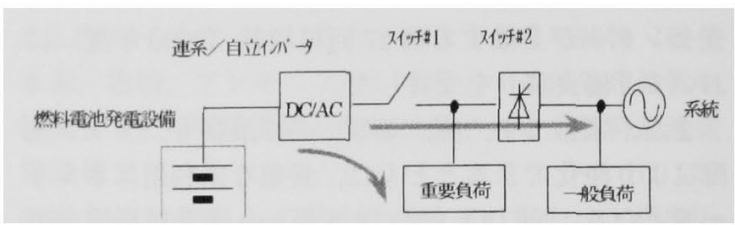

図 8 系統連系/自立運転切換えシステム

備燃料への自動切換え機能の併用により電源信頼性を 極めて高いレベルとすることができる。

その結果, 長時間運転特性に優れる燃料電池は常用 のコージェネレーションシステムを基本とした運転を 継続しつつ, UPS と蓄電池を組合せた高信頼性電源 システムの機能を同時に実現することができ, 高効率 で経済的かつ環境に優しい高信頼電源システムを実現 できる。

本システムに代表される各種重要負荷対応電源は, 東京ガス, 大阪ガス, 東邦ガスと当社が共同でシステ ム開発しており, 現在, 大阪工業技術研究所, 東京都 立科学技術大学及び東邦ガス本社の 3 ヶ所で順調に運 転中である。高品質・高信頼性電源としての燃料電池 システムは, 今後の情報技術（IT）の普及に向け， 研究所や大学のみならず, オフィスや病院等の民間施 設への導入も期待されている。

\section{4. 固体高分子形燃料電池（PEFC）の開発動向}

\subsection{PEFC の開発経緯}

PEFCは, アポロより前の 1960 年代初頭のジェミ ニに探用された燃料電池であったが，電解質に使用さ れた固体高分子膜の性能, コスト, 耐久性等の問題に より, 地上向けの開発は 20 年以上の空白期間を生む 結果となった。

1980 年代に入り,デュポン社が高性能ナフィオン 膜（フッ素系ポリマー樹脂）を開発し，引続きダウ社 


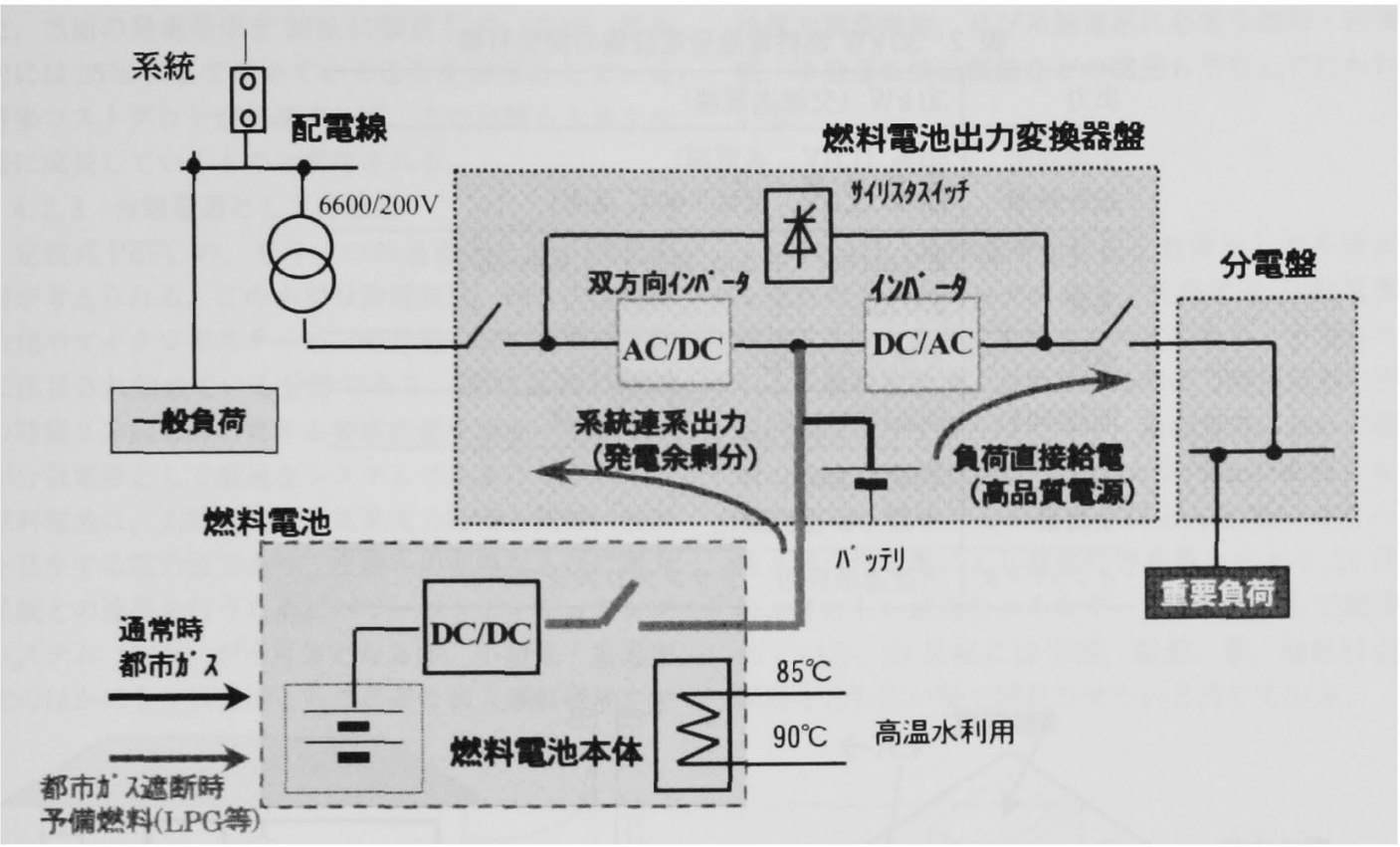

図 9 高品質・高信頼性電力供給システム

が膜の薄膜化に成功したことから，PEFC の開発が再 開され,カナタのバラード社が 1990 年代初めに純水 素を燃料としたバスへの実証機搭載を開始した。 PEFC は電池動作温度が $80^{\circ}$ 以下であるため起動時 間が短く，エネルギー出力密度を高くとれること，し かも電解質が固体であることから, 車載用としての要 求仕様（軽量, コンバクト, 耐震, 量産効果) に対し ては，各種然料電池の中で最も近い位置にある。また， 排熱回収温度が低いことから冷房の熱源には適用しが たいが，数十 $\mathrm{kW}$ 級のオンサイト型から $500 \mathrm{~W}$ 級の 家庭/携帯用までの市場向けとして, 発電と暖房/給湯 を併せ持った熱電併給装置として活用が可能であ ク,21 世紀初頭の商用化を目指して世界の電機メ一カ, 自動車メーカ, ベンチャー会社による開発競争が展開 されている。

日本における PEFC の開発は 1990 年代頃から検討 が始まり，NEDOのプロジェクトが1992 年から始ま った。このプロジェクトは 1996 年からフェーズIに 入り，電池スタックやシステムの開発が行われている。 一方, 自動車用燃料電池の開発気運の高まりの中で NEDO プロジェクト以外にも，多くの企業が開発を 開始しており，特に自動車会社が積極的な活動を行っ ており, 電池, 改質器等の主要部品をはじめとする各 構成機器の要素研究を含む総合的開発を推進している。 また，量産規模という点においても，他の形式の燃料
電池が基本的には発電用のみであるのに対して, PEFC は自動車用という大きな潜在市場があり，劇的 なコストダウンが実現できる可能性がある。

\section{2 コージェネレーションシステムへの適用}

現在, 数多くの企業等で PEFCのコージェネレー ションシステムへの適用開発が始まっているが，以下 に代表的なシステムを紹介する。

\subsubsection{NEDO プロジェクト}

当社は, 1992 年度より NEDO からの委託研究とし

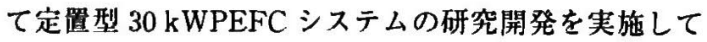
いる。主要機器とともにシステム全体の設計，製作を 行っており, 2000 年度末には試運転を開始した。本フ ラントは日本における PEFCの本格的なコージェネ レーションシステムへの適用の第一歩として電気出力 $30 \mathrm{~kW}, 60 \sim 80^{\circ} \mathrm{C}$ の温水供給タイプのシステム開発が 行われており, 然料はPAFC と同様に, 都市ガスゃ LPGが考えられている。

表 $2 に 30 \mathrm{~kW}$ 燃料電池発電設備の開発目標を，ま た図 $10 に 30 \mathrm{~kW}$ 機のパッケージ外観図と内部構成機 器を示す。この $30 \mathrm{~kW}$ システムは, 分散電源として の重要な使命の一つである省エネ性や地球環境への貢 献に配虑し, 開発目標として発電効率 $40 \%$ 以上と高 く設定している。また，システム運転圧力は，発電効 率, 運転信頼性, 制御性等から常圧 (大気圧 $+\alpha)$ と している。さらに, パッケージ寸法と重量は, ビル等 


白岩義而

表 $230 \mathrm{~kW}$ 燃料電池発電設備の開発目標

\begin{tabular}{l|l}
\hline 出力 & $30 \mathrm{~kW}$ (交流送電端) \\
\hline 発電効率 & $40 \%(\mathrm{LHV}$, 送電端 $)$ \\
総合効率 & $80 \%\left(\mathrm{LHV}\right.$, 電気 $+60^{\circ} \mathrm{C}$ 温水 $)$ \\
\hline サイズ & $2.0 \mathrm{~m}$ (幅 $) \times 1.5 \mathrm{~m}$ (奥行) $\times 1.8 \mathrm{~m}$ (高さ $)$ \\
重量 & $2.0 \mathrm{ton}$ \\
\hline 燃料 & 天然ガス $/ \mathrm{LPG}$ \\
\hline 電池本体 & 運転圧力 $:$ 常圧, 内部加湿方式 \\
\hline 燃料 & 水蒸気改質 \\
改質系 & 2 段 CO 選択酸化 \\
\hline インバータ & 系統連系専用, トランスレスシステム \\
\hline
\end{tabular}

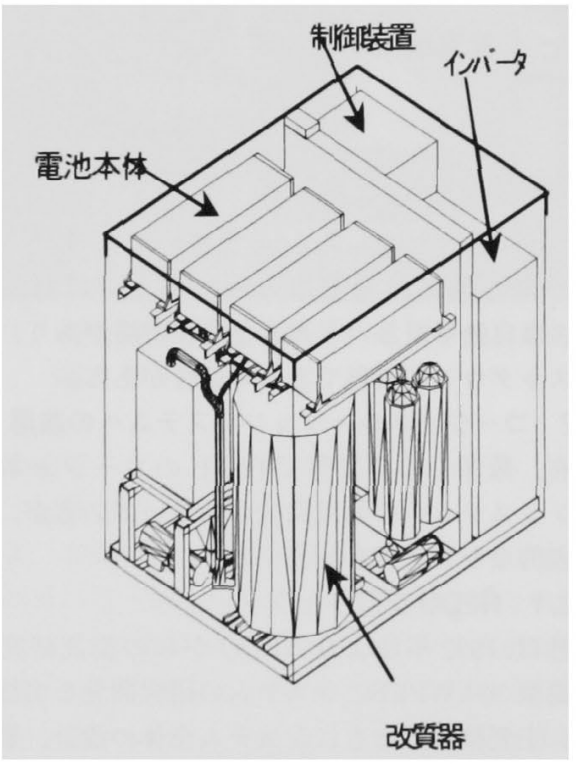

図 $1030 \mathrm{~kW}$ 機のパッヶージ外観図と 内部構成機器

の屋内への般入と設置を考虑して設定した。このシス テムはコージェネレーション設備としての利用に加え， 停電時のバックアップとしての保安電源, さらにはコ ンピュータや通信設備等への高品質電源, 直流電源等 としての活用も可能であり, 将来の適用市場の広がり が期待されている。

\section{2 家庭用コージェネレーションシステム}

PEFC は，その特性から家庭用小型コージェネレー ションシステムにも適しており,ガス会社や電機メー カなどが開発を開始している。

当社では家庭用 PEFC として, $1 \mathrm{~kW}$ 級システムの

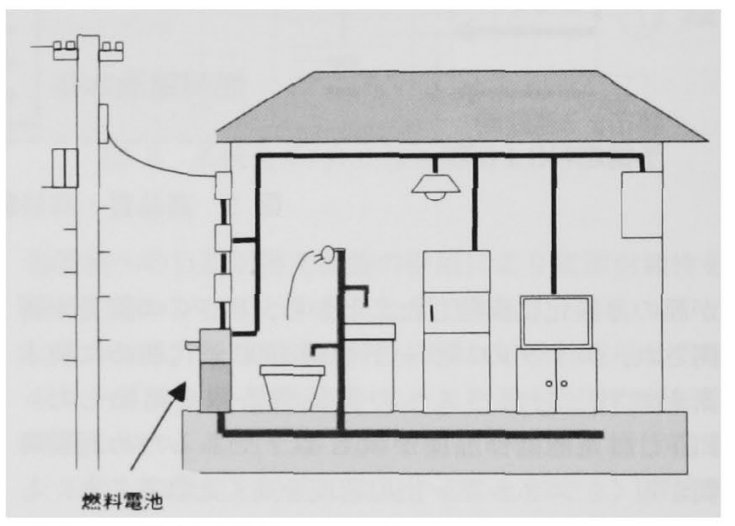

図 11 燃料電池を用いた家庭用システムの概念図

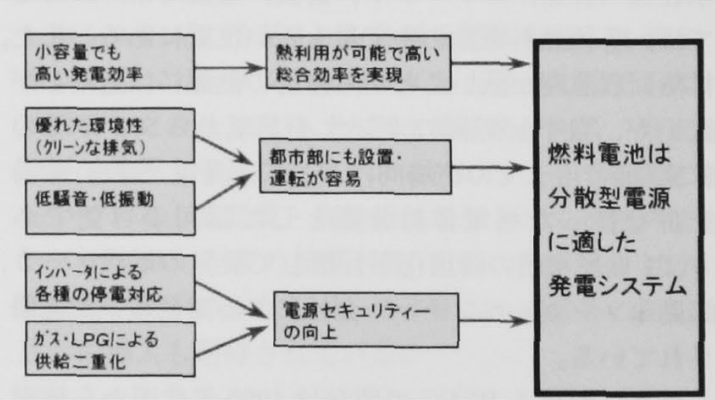

図 12 燃料電池の特徵と分散電源に対する要求仕様

開発も行っている。平成 11 年度にPEFCによる缶飲 料の自動販売機を試作し, 運転デモも行っており,こ の際の経験と技術が本システムの開発に大いに生かさ れている。図11に燃料電池を用いた家庭用システム

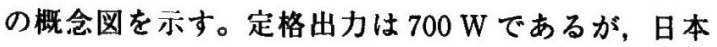
の一般家庭における電気と熟の消費パターンをもとに， 経済性と環境性を考慮に入れて設定した值である。ま 
た，当面の発電効率を $30 \%$ に設定しているが，将来 的には $35 \%$ にまで高めていくことを目標としている。 将来コストダウンが加速すれば，この分野も大きな市 場に成長していくものと期待される。

\subsection{3 分散電源としての適用}

定置式 PEFC の, もう一つの適用として分散電源 用が考えられる。この小型分散電源は, 昨今の電力自 由化やマイクロガスタービンの登場などの影箕で, 特 に注目され始めている分野である。図 12 に燃料電池 の特徽と分散電源に対する要求仕椂を示す。燃料電池 が分散電源として最適なシステムであることが判る。 燃料電池は, 太陽光発電, 電池電力眝蔵と同様に直流 を発生する電力源であり, 交流への変換ならびに電力 系統との連系を行うためにパワーコンディショニンク システム (PCS) が不可欠となるが, 小型化・高効率 化のほかにも分散電源として必要な自立運転機能や無
効電力調整機能, 及び系統連系に必要な制御・保護機 能, 単独運転検出機能などの開発も平行して行われて いる。

\section{5. あとがき}

21 世紀は, 地球温暖化防止を最優先した多種多様 な然料のベストミックス化と, 大型電源/分散電源の ベストミックス化を重視する時代になると予想されて いる。然料電池は, その高い効率が二酸化炭素の排出 量削減に寄与するだけでなく，地球規模において酸性 雨の, また地域社会において大気污染の原因となる NOx,SOx，ばいじんの排出がほとんどないクリーン 性と静止型発電による静肃性等を備えており,21 世紀 にふさわしい最適なエネルギー変換装置として期待さ れている。21世紀には宇宙, 船舶, 車, 地域社会, 家庭を含む広い場で開花させたいと念じている。 


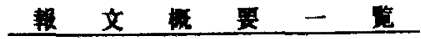

大規模風力発電の導入事例とその特長

一苫前グリーンヒルウィンドパークー

株式会社トーメン 電力事業本部第一部 中村 成人

\section{1. 風力発電の現状}

世界的な地球㻴境への意識の高まりを背景に, 90 年代半ば以降欧米先進各国を中心に風力発電に代表 されるいわゆる再生可能エネルギーの導入が急速に進んでいる。現在全世界で設置されている風力発電 の棇容量は約 $12,500 \mathrm{MW}$, 最大のドイッで 4, $445 \mathrm{MW}$ であるのに対し，未だ離陸期にある我が国の設 置済み容量は $100 \mathrm{MW}$ 程度と推測される。

トーメンは 1987 年に米国カイリフォルニア州におけるブロジェクトを始めとして，現在までに欧米， 日本の 6 ヶ国で合計約 $700 \mathrm{MW}$ の風力発電設備を建設・運営中である。

2. 苫前グリンヒルウィンドパーク

1999 年 11 月, トーメンは日本で初めて且つ最大規模の集合型風力発電施設（1 MW × 20）を，北海 道苫前町に完成し连転を開始した。この施設は通産大臣の新エネルギー事業者としての認定に基づく補 助金対象事亲であり，且つ 17 年に亘り発電電力の全量を北海道電力に売電する我が国初の風力発電に よる卸電力事莱でもある。その特長は下記の 4 点である。

・大規模化による大幅なコストタウン（風車はデンマーク製を採用）

・椱数の薑転員を常駐させることによる安全・安定操業の確保

- 周辺即境との調和

- 地域社会との共生

3. 風力発電の将来

欧米各国は政策的支振を含めて，今後供皘極的に風力発電の導入を促進していく方針を明らかにして いる。日本においても渐く風力発電を始めとする自然エネルギー導入に関する本格的な関心と議論が高 まるところとなって来だ。風力発電の本格的且つ大量の導入に当たっては技術的, 経済的な課題もある が,これらを踏まえて種々の観点から, 国民の一人一人が自分自身の明日のライフスタイルとエネルギ 一を選択する時期に来ているものと考えるものである。

(本文 64 ページ)

\section{燃料電池の開発状況}

\section{株式会社東芝 電力システム社然料電池事業推進部 白岩 義三}

燃料電池は小型でも高い発電効事 $(40 \%:$ LHV) を有し, 㕵素酸化物の発生量が少なく, 硫黄酸化 物やばいしんの発生量がなく，低䮜音でしかも振動もほとんどないことから環境特性に優れた発電装置 として, 懪境問題の重要さが增している現在, 分散電源やコージェネレーションシステム, さらには電 気自動車の電源などへの適用に期待が高まっている。中でも，りん酸形燃料電池（PAFC）は，その開 発が完了し，本格的普及を推進すべき段階に到達している。都市ガスや LPGを原燃料とした，燃料雷 池の発電電力とそれに付随して生成される熱を使用するコージェネレーションとしての利用形態が進む 中, 食品・紙バルプ工場等の排水や下水污泥の嫌気性処理の際に発生するバイオガスや消化ガス, 半導 体彆造工場から排出される排メタノールのような未利用エネルギーを燃料電池の原然料とする新しいフ プリーションが開発され，発電革転を開始している。さらに、燃料電池の特徽を生かした高品質・高 信頼性電力供給システムへの道用など，新しいアブリケーションがどんどん開発されている。

また，固体高分子形燃料電池（PEFC）は定置用から自動車用まで幅広い用途に遧用が可能であり， 